\title{
IMPLEMENTASI PEMBELAJARAN PEER TEACHING PADA MATA PELAJARAN PENDIDIKAN AGAMA ISLAM DI SMA KARYA IBU PALEMBANG SUMATERA SELATAN
}

\author{
MUNIRUL IKHWAN \\ (STIE APRIN Palembang, Sumatera Selatan) \\ Email: munirul_ikhwan@yahoo.co.id
}

\begin{abstract}
The purpose of this study is to describe the activities of Islamic religious education and the implementation of peer teaching on PAI subject at SMA Karya Ibu Palembang. Therefore, this research is a descriptive study, the research that explores the description a symptom, specific activities with the data qualitatively. The data analysis used in this study is interactive model (data reduction, data display, data verification).

The findings of the study showed that the school policy to the implementation of Islamic education is; that PAI subject was taught in SMA Karya Ibu with the time allocation 3 hours of subject per week. Two hours of subject was a core school hours, while the one-hour subject is a subject hours plus extra for religious programs. The implementation of peer teaching on PAI subject can be quite successful, but it still needs to be improved further. Because there are some things that need to be considered in order to improve the quality of learning, especially in PAI subject at SMA Karya Ibu Palembang in the future time.
\end{abstract}

\begin{abstract}
Abstrak
Tujuan penelitian ini adalah mendeskripsikan kegiatan pendidikan agama Islam dan implementasi pembelajaran peer teaching pada mata pelajaran PAI di SMA Karya Ibu Palembang. Oleh karena itu, penelitian ini merupakan penelitian deskriptif, yaitu penelitian yang berusaha mensdeskripsikan suatu gejala, peristiwa atau kejadian tertentu dengan data yang bersifat kualitatif. Analisis data yang digunakan dalam penelitian ini adalah analisis data model interaktif, yaitu melalui proses reduksi, displai dan verifikasi.

Temuan dalam penelitian ini yaitu bahwa kebijakan sekolah terhadap pelaksanaan Pendidikan Agama Islam yaitu; bahwa PAI diajarkan di SMA Karya Ibu dengan alokasi waktu 3 jam pelajaran per minggu. Dua jam pelajaran merupakan jam pelajaran inti, sedangkan satu jam pelajaran merupakan jam pelajaran tambahan untuk program agama plus. Implementasi pembelajaran peer teaching pada mata pelajaran PAI dapat dikatakan cukup berhasil, akan tetapi masih perlu ditingkatkan lagi. Karena itu ada beberapa hal perlu diperhatikan demi meningkatkan
\end{abstract}


kualitas pembelajaran khususnya pada mata pelajaran PAI di SMA Karya Ibu Palembang pada masa yang akan datang.

\section{Kata Kunci: Implementasi, Peer Teaching, PAI, Active Learning}

\section{Pendahuluan}

Pendidikan diartikan sebagai segala sesuatu yang mengalami proses perubahan ke arah yang lebih baik ${ }^{1}$. Sementara Undang-Undang No. 20 Tahun 2003 dalam ketentuan umum pasa1 ayat 1 menyatakan bahwa pendidikan adalah usaha sadar dan terencana untuk mewujudkan suasana belajar dan proses pembelajaran agar peserta didik secara aktif mengembangkan potensi dirinya untuk memiliki kekuatan spiritual keagamaan, pengendalian diri, kepribadian, kecerdasan, akhlak mulia, serta keterampilan yang diperlukan dirinya, masyarakat, bangsa dan negara.

Pengertian pendidikan Islam adalah suatu sistem kependidikan yang mencakup seluruh aspek kehidupan yang dibutuhkan oleh hamba Allah meliputi kebutuhan untuk dunia dan akhirat. Sedangkan tujuannya adalah untuk merealisasikan cita-cita ajaran Islam yang membawa misi bagi kesejahteraan umat manusia sebagai hamba Allah lahir dan batin, dunia dan akhirat ${ }^{2}$.

Proses belajar mengajar yang juga disebut pembelajaran, merupakan realisasi dari konsep-kosep dalam pendidikan. Sehubungan dengan hal ini, belajar adalah peran siswa dalam proses mengkonstruksi pengetahuan, baik yang alami maupun manusiawi. Proses ini adalah suatu proses yang aktif. Beberapa faktor, seperti pengalaman, pengetahuan yang dipunyai, kemampuan kognitif, dan lingkungan berpengaruh terhadap hasil belajar. Mengajar adalah peran guru yaitu berupa proses membantu seseorang untuk membentuk pengetahuannya sendiri. Mengajar bukanlah mentransfer pengetahuan dari orang yang sudah tahu (guru) kepada yang belum tahu (murid), melainkan membantu murid agar dapat mengkonstruksi secara mandiri pengetahuan-pengetahuan lewat kekuatan dirinya terhadap fenomena-fenomena dan objek yang ingin diketahui ${ }^{3}$. Makna belajar adalah adanya perubahan tingkah laku atau penampilan dengan melalui serangkaian kegiatan, misalnya dengan membaca, mengamati, mendengarkan, meniru dan sebagainya. Belajar akan memperoleh hasil yang lebih baik hasilnya apabila subyek belajar itu mengalami atau melakukannya ${ }^{4}$.

Menyikapi perihal di atas, maka diperlukan suatu perumusan dan pemilihan penggunaan strategi pembelajaran yang tepat, terarah, efektif dan efisien dalam

1 Jasa Ungguh Muliawan, Pendidikan Islam Integratif, (Yogyakarta: Pustaka Pelajar, 2005), 99.

2 M. Arifin, Ilmu Pendidikan Islam: Suatu Tinjauan Teoritis dan Praktis Berdasarkan Pendekatan Indisipliner, (Jakarta: Bumi Aksara, 1991), 44.

3 Jasa Ungguh Muliawan, Pendidikan Islam Integratif, (Yogyakarta: Pustaka Pelajar, 2005), 134.

${ }^{4}$ A.M. Sardiman, Interaksi \& Motivasi Belajar Mengajar, (Jakarta: PT. Raja Grafindo Persada, 2001), . 
pembelajaran, agar proses pembelajaran akan benar-benar menghasilkan peserta didik yang berkepribadian, memiliki keterampilan dalam menjalani kehidupannya dengan baik 5 .

Silberman memodifikasi paham pembelajaran dengan konsep active learning sebagai pengembangan dari apa yang telah dinyatakan oleh Confusius bahwa ; apa yang saya dengar, saya lupa. Apa yang saya dengar dan lihat, saya ingat sedikit. Apa yang saya dengar, lihat dan tanyakan atau diskusikan dengan beberapa teman lain, saya mulai faham. Apa yang saya dengar, lihat dan tanyakan, diskusikan dan lakukan saya memperoleh pengetahuan dan keterampilan. Apa yang saya ajarkan pada orang lain, saya kuasaí6.

Peer teaching merupakan salah satu dari strategi pembelajaran berbasis active learning. Strategi ini pada praktiknya menempatkan seluruh tanggung jawab untuk mengajar pada peserta didik sebagai anggota kelas. Siswa di dalam proses belajar mengajar diarahkan agar dapat berperan menjadi guru dan menerangkan materi yang sedang dipelajari kepada teman-temannya di kelas.

Berkaitan dengan hal tersebut di atas, penulis merasa tertarik dan bermaksud untuk mengadakan pengkajian dalam bentuk penelitian terhadap "Implementasi Pembelajaran Peer Teaching pada Mata Pelajaran Pendidikan Agama Islam di SMA Karya Ibu Palembang".

\section{Konsep Pembelajaran Peer Teaching}

Pada pembelajaran model peer teaching, karakter belajar aktif dapat dilihat dari unsur-unsur aktifitas yang dilakukan oleh peserta didik yaitu: aktivitas membaca, menulis dan mendengarkan, menganalisa, membuat gambar (poster), menyajikan informasi. Adapun model-model pembelajaran Peer Teaching adalah sebagai berikut:

a. Group To Group Exchange (Pertukaran Dari Kelompok Ke Kelompok)

Prinsip dari model pembelajaran Group To Group Exchange ini adalah satu kelompok diwakili oleh seorang juru bicara mengajarkan kepada kelompokkelompok lainnya.

b. Jigsaw Learning (Belajar melalui Jigsaw)

Jigsaw Learning merupakan sebuah teknik yang dipakai secara luas yang memiliki kesamaan dengan model "Pertukaran Dari Kelompok Ke Kelompok" (Group To Group Exchange). Perbedaannya adalah bahwa dalam model Jigsaw Learning setiap peserta didik mengajarkan sesuatu pada peserta didik lainnya.

Di dalam kelompok "jigsaw learning" masing-masing peserta didik mengajarkan kepada anggota yang lainnya materi yang dipelajarinya secara berurutan dari materi ke satu, dua dan tiga.

c. Every One Is A Teacher Here (Setiap Peserta Didik adalah Pengajar)

5 Zamroni, Pendidikan dan Demokrasi dalam Transisi (Prakondisi Menuju Era Globalisasi), (Jakarta: Muhammadiyah, 2007), 228.

${ }^{6}$ Mel Silberman, Active Learning: 101 Strategi Pembelajaran Aktif, (Yogyakarta: YAPPENDIS, 2001), 2. 
Pembelajaran model ini digunakan agar di dalam proses belajar diperoleh partisipasi peserta didik yang besar dan mengembagkan tanggung jawab individu. Karena dengan model ini setiap peserta diberi kesempatan untuk bertindak sebagai seorang pengajar terhadap peserta didik lainnya.

d. Peer Lessons (Pelajaran Teman Sebaya)

Peer Lessons adalah model pembelajaran yang mengembangkan "peer teaching" dalam kelas yang menempatkan seluruh tanggung jawab untuk mengajar kepada peserta sebagai anggota kelas. Langkah-langkah model pembelajaran ini adalah guru membentuk kelompok dalam kelas sesuai dengan jumlah topik yang dipelajari. Selanjutnya topik pelajaran dibagikan kepada masing-masing kelompok untuk dipelajari. Sebelum masing-masing kelompok menerangkan materi kepada sisa kelas lainnya guru memberikan sejumlah informasi, konsep atau keahlian bagaimana cara mengajar pada yang lain.

e. Student Created Case Studies (Studi Kasus yang Dibuat Peserta Didik)

Studi kasus disinyalir merupakan suatu metode belajar terbaik. Suatu tipe diskusi kasus yang memfokuskan issu menyangkut situasi yang nyata atau contoh cara mengambil tindakan dan pelajaran yang dapat diambil, dan caracara mengendalikan atau menghindari situasi yang akan datang. Model ini memungkinkan peserta didik menciptakan studi kasus sendiri. Siswa dibagi menjadi pasangan duet atau trio. Kepada masing-masing pasangan diberikan informasi mengenai tujuan studi kasus adalah mempelajari topik dengan menguji situasi nyata atau contoh yang merefleksikan topik. Selanjutnya guru memberikan waktu secukupnya bagi pasangan untuk mengembangkan situasi kasus kecil dengan mendorong memberi contoh untuk didiskusikan atau memberi problem untuk dipecahkan yang relevan dengan materi pelajaran di dalam kelas.

f. In The News (Dalam Berita)

Model pembelajaran "In The News" (Dalam Berita) merupakan sebuah cara yang menarik agar peserta didik terlibat dan menimbulkan ketertarikan mereka pada materi pelajaran bahkan sebelum mereka masuk kelas. Pendekatan "In The News" ini juga akan menghasilkan kekayaan materi dan informasi yang dapat dibahas oleh seluruh peserta didik.

Pembelajaran model ini diawali dengan pemberian tugas oleh guru kepada peserta didik agar masing-masing membawa artikel, head line news, editorial atau kartun yang sesuai dengan topik pelajaran. Setelah kelas dimulai guru membagi peserta didik menjadi sub kelompok dan mengarahkan agar mereka mendiskusikan artikel yang mereka miliki.

Setelah sub kelompok selesai mendiskusikan artikelnya, berikutnya peserta didik kembali ke kelas besar dan wakil dari masing-masing kelompok membahas artikel yang telah didiskusikan dengan peserta lain.

g. Poster Session (Penggunaan Poster Pada Sesi)

Metode poster session ini merupakan sebuah alternatif yang tepat untuk menginformasikan materi pelajaran kepada peserta didik secara cepat, 
menangkap imajinasi peserta didik, dan merangsang pertukaran ide antar mereka.

\section{Hasil Penelitian}

1. Implementasi Pembelajaran Peer Teaching pada mata pelajaran Pendidikan Agama Islam

Peer teaching merupakan model pembelajaran yang berbasis active learning salah satu model yang telah diuji cobakan penggunaannya di SMA Karya Ibu Palembang sejak ditetapkannya penggunaan Kurikulum Berbasis Kompetensi pada tahun 2004. Penggunaan peer teaching juga dilakukan pada pembelajaran mata pelajaran Pendidikan Agama Islam.

1. Pembelajaran Peer Teaching pada mata pelajaran Pendidikan Agama Islam di SMA Karya Ibu Palembang

a. Pembelajaran Pendidikan Agama Islam Kelas X

1) Persiapan Pembelajaran

Persiapan yang dilakukan oleh Ibu Suparmi, S.Ag. dalam rangka penggunaan model pembelajaran Peer Teaching jenis Every One is A Teacher Here ini adalah menyiapkan Rencana Persiapan Pembelajaran (RPP) yang akan dituangkan dalam pembelajaran. Komponen yang dipersipkan adalah menentukan Kompetensi Dasar, Materi Pokok dan Uraian Materi Pokok, Pengalaman Belajar, Indikator, Metode, Estimasi Waktu, Penilaian dan Penentuan Sumber Belajar.

2) Pelaksanaan Pembelajaran

Setelah tahap persiapan selesai dilakukan, selanjutnya penulis melakukan pengamatan terhadap pelaksanaan pembelajaran Pendidikan Agama Islam yang dilakukan oleh Suparmi, S.Ag, guru agama Islam kelas $X$ di SMA Karya Ibu Palembang. Cakupan materi atau lingkup belajar yang diharapkan dikuasai oleh siswa adalah; Memahami Sumber Hukum Islam, Hukum Taklifi dan Hukum Ibadah. Adapun kompetensi yang dituntut oleh kurikulum meliputi beberapa hal sebagai berikut :

(a) Menjelaskan arti Al-Qur'an, Hadits dan Ijtihad

(b) Menjelaskan Kedudukan Al-Qur'an, Hadits dan Ijtihad

(c) Menjelaskan fungsi Al-Qur'an, Hadits dan Ijtihad

Pembelajaran diawali dengan salam dan dilanjutkan doa bersama. Setelah memeriksa kehadiran siswa kemudian guru memberikan penjelasan tentang topik atau materi pelajaran dan menjelaskan tujuan pembelajaran yang akan dicapai. Selanjutnya guru memberikan pengarahan dan memerintahkan pada siswa agar membaca buku pelajaran sesuai dengan topik yang dibahas pada pertemuan tersebut yaitu materi tentang sumber-sumber hukum hukum Islam.

Setelah waktu yang disediakan untuk membaca materi pelajaran telah selesai, kemudian Suparmi, S.Ag membagikan kartu indeks 
kepada setiap siswa dan memerintahkan siswa agar masing-masing membuat satu pertanyaan yang berhubungan dengan materi Sumber Hukum Islam, Hukum Taklifi dan Hukum Ibadah.

Kartu indeks yang berisi pertanyaan dari peserta didik dikumpulkan oleh Suparmi S.Ag. Semua kartu dicampur atau dikocok sebelum dibagi kembali kepada peserta didik. Setelah kartu selesai dikocok kemudian Suparmi, S.Ag membagikan kembali secara acak kepada anggota kelas. Guru agama berusaha agar pertanyaan tidak kembali kepada pembuat pertanyaan.

Kemudian Suparmi, S.Ag menginformasikan kepada seluruh siswa agar membaca atau merenungkan pertanyaan dalam kartu indeks yang mereka pegang dan berusaha mencari jawabannya. Setelah waktu yang diberikan untuk memahami dan mencari jawaban dari pertanyaan diangap cukup kemudian guru agama memanggil agar maju ke depan kelas salah satu siswa sebagai sukarelawan untuk membacakan pertanyaaan yang ada pada kartu indeks yang diterimanya sekaligus menerangkan jawabannya kepada siswa yang lainnya.

3) Evaluasi

Dari evaluasi yang dilakukan tersebut diketahui dari 34 siswa, 33 yang mengikuti ulangan blok 2 ini kesemuanya mencapai nilai rata-rata di atas Standar Ketuntasan Belajar Minimal (SKBM) kecuali satu siswa yang mendapatkan nilai sama dengan Standar Ketuntasan Belajar Minimal mata pelajaran Pendidikan Agama Islam yaitu 70. Sedangkan satu siswa bernama Welda tidak mengikuti ulangan karena beragama non Islam.

b. Pembelajaran Pendidikan Agama Islam Kelas XI

1) Persiapan Pembelajaran

Persiapan yang dilakukan oleh Ibu Dra. Hj. Siti Ngatimah dalam rangka penggunaan model pembelajaran peer teaching ini adalah menyiapkan Rencana Persiapan Pembelajaran (RPP) yang akan dituangkan dalam pembelajaran. Komponen yang dipersipkan adalah menentukan Kompetensi Dasar, Materi Pokok dan Uraian Materi Pokok, Pengalaman Belajar, Indikator, Metode, Estimasi waktu, Penilaian dan Penentuan Sumber Belajar.

Hal yang dipersiapkan Ibu Dra. Hj. Siti Ngatimah dalam rangka penerapan pembelajaran peer teaching jenis Jigsaw (Model Team Ahli) ini setelah perangkat pembelajaran adalah menyiapkan materi pelajaran secara tertulis dan membagi menjadi beberapa topik untuk dibagikan dan didiskusikan oleh siswa dalam kelompok topik sebelum siswa masuk dalam kelompok jigsaw (model team ahli). Hal itu dilakukan karena dengan diketahui berapa topik materi yang ada, maka memudahkan untuk menentukan berapa jumlah kelompok yang akan dibentuk.

2) Pelaksanaan Pembelajaran 
Setelah tahap persiapan telah selesai dilakukan, selanjutnya penulis melakukan pengamatan terhadap pelaksanaan pembelajaran Pendidikan Agama Islam yang dilakukan oleh Dra. $\mathrm{Hj}$. Siti Ngatimah, guru agama Islam kelas XI di SMA Karya Ibu Palembang. Cakupan materi atau lingkup belajar yang diharapkan dikuasai oleh siswa adalah Memahami Sumber Hukum Islam tentang Mu'amalah. Adapun kompetensi yang dituntut oleh kurikulum meliputi beberapa hal sebagai berikut :

a) Menjelaskan ketentuan hukum jual beli

b) Menjelaskan dalil-dalil tentang jual beli

c) Menjelaskan hukum jual beli menurut syari'ah

d) Menjelaskan macam-macam jual beli

e) Menjelaskan pengertian riba

f) Menjelaskan macam-macam riba

Pembelajaran diawali dengan salam dan doa bersama. Setelah mengecek kehadiran siswa kemudian guru menerangkan topik atau materi pelajaran dan menjelaskan tujuan pembelajaran yang akan dicapai. Selanjutnya guru membagi kelas menjadi empat kelompok dan memberikan kepada masing-masing kelompok satu topik materi yang harus didiskusikan atau di bahas oleh kelompok tersebut. Kelompok satu membahas tentang hukum jual beli, kelompok dua membahas dalil-dalil tentang jual, kelompok tiga membahas tentang jual beli menurut syari'ah dan macam-macam jual beli, sedangkan kelompok empat membahas tentang riba dan macam-macamnya.

Setelah waktu yang disediakan untuk diskusi dalam kelompok topik selesai, kemudian guru agama membentuk kelompok baru (jigsaw/team ahli) yang anggotanya terdiri dari perwakilan dari empat kelompok topik yang dibentuk diawal pelajaran. Setelah team ahli (jigsaw) terbentuk, selanjutnya guru memerintahkan agar masing-masing perwakilan dari kelompok topik yang ada dalam kelompok jigsaw untuk menyampaikan presentasi atau penjelasan terhadap anggota dalam kelompok kelompok tentang topik yang dibahasnya. Dimulai dari anggota ahli pertama dan dilanjutkan ahli kedua, ketiga dan keempat sampai semua anggota ahli menjelaskan materi yang dibidanginya.

3) Evaluasi

Dari pelaksanaan evaluasi yang dilakukan oleh Ibu Dra. Hj. Siti Ngatimah tersebut, 41 siswa mengikuti ulangan, 41 siswa tersebut semuanya mencapai nilai rata-rata di atas Standar Ketuntasan Belajar Minimal (SKBM) yang ditetapkan untuk mata pelajaran Pendidikan Agama Islam yaitu 70.

c. Pembelajaran Pendidikan Agama Islam Kelas XII

1) Persiapan Pembelajaran 
Persiapan yang dilakukan oleh guru agama dalam rangka penggunaan model pembelajaran peer teaching ini adalah menyiapkan Rencana Persiapan Pembelajaran (RPP) yang akan dituangkan dalam pembelajaran. Komponen yang dipersiapkan adalah menentukan Kompetensi dasar, Materi Pokok dan Uraian Materi Pokok, Pengalaman Belajar, Indikator, Metode, Estimasi Waktu, Penilaian dan Penentuan Sumber Belajar.

Komponen-komponen yang perlu disiapkan adalah sama dengan pembelajaran-pembelajaran pada umumnya. Perbedaannya terletak pada pemilihan model atau strategi pembelajaran yaitu model peer teaching. Dari beberapa jenis pembelajaran yang ditawarkan model peer teaching Mirtha Antoni, M.Ag. memilih jenis yang lebih akomodis yaitu jenis Group To Group Exchange yang berarti pertukaran dari kelompok ke kelompok.

2) Pelaksanaan Pembelajaran

Setelah tahap persiapan selesai dilakukan, selanjutnya dalam pengamatan penulis terhadap pelaksanaan pembelajaran Pendidikan Agama Islam yang dilakukan oleh guru agama Islam kelas XII di SMA Karya Ibu. Dari data perangkat pembelajaran yang dibuat oleh guru agama diketahui cakupan materi atau lingkup belajar yang diharapkan dikuasai oleh siswa adalah Memahami Sumber Hukum Islam, tentang hukum keluarga tentang munakahat. Adapun kompetensi yang dituntut oleh kurikulum meliputi beberapa hal sebagai berikut :

a) Menjelaskan arti ketentuan hukum perkawinan dalam Islam.

b) Menjelaskan Hikmah perkawinan.

c) Menjelaskan ketentuan perkawinan menurut perundangundangan di Indonesia.

Setelah mengucapkan salam dan berdoa bersama, guru agama kemudian membuka pertemuan dengan membaca basmalah. Guru agama tidak lupa mengecek kehadiran siswa dan diteruskan kemudian dengan penjelasan mengenai topik atau materi pelajaran dan menjelaskan tujuan pembelajaran yang akan dicapai dalam pertemuan tersebut. Selanjutnya guru memberikan pengarahan memerintahkan pada siswa agar membentuk kelompok menjadi enam kelompok.

Guru agama kemudian memberikan topik bahasan kepada masing-masing kelompok. Untuk kelompok pertama membahas tentang rukun nikah dan muhrim, kelompok kedua membahas tentang kewajiban suami atau isteri, kelompok ketiga membahas tentang talak, kelompok keempat membahas tentang ruju' dan kelompok kelima membahas tentang hikmah pernikahan serta kelompok keenam membahas tentang ketentuan undang-undang perkawinan di Indonesia. 
Selama kurang lebih 25 menit masing masing kelompok mendiskusikan materi bahasannya. Selama siswa berdiskusi dalam kelompok guru agama berkeliling mengamati sambil memberi pengarahan kepada kelompok yang sedang berdiskusi agar diskusi berjalan sebagaimana mestinya.

Setelah waktu yang diberikan untuk bediskusi selesai, selanjutnya guru agama menginformasikan agar masing-masing kelompok menunjuk satu orang untuk menjadi juru bicara yang akan mewakili mempresentasikan hasil diskusi dari topik yang dibahas dalam kelompoknya.

Pada akhir pembelajaran, Mirtha Antoni, M.Ag. memberikan komentar terhadap penampilan para juru bicara dan kelompok berisi pujian dan saran. Selain itu guru juga memberikan kesimpulan pokok pembelajaran yang dilakukan pada pertemuan tersebut bahwa di dalam Islam pernikahan merupakan perbuatan ibadah dan akan mendapatkan imbalan pahala dari Allah SWT. Guru agama pada akhir juga memberikan penekanan kepada siswa bahwa di dalam melaksanakan syariat Islam khususnya dalam hal pernikahan harus berpedoman kepada tuntunan yang ada di dalam Al-Qur'an, Hadits dan Ijtihad.

3) Evaluasi

Pada evaluasi yang dilakukan tersebut, dari 41 siswa yang yang ada di kelas XII IPA, 2 diantaranya tidak mengikuti ulangan karena beragama non Islam. Sedangkan dari 39 siswa yang mengikuti ulangan hanya satu siswa yang tidak mencapai Standar Ketuntasan Belajar Minimal.

\section{Penutup}

1. Kesimpulan

Berdasarkan hasil interview, telaah terhadap data-data yang meliputi data profil sekolah, dokumen kurikulum, perangkat pembelajaran serta pengamatan terhadap implementasi pembelajaran di dalam kelas, peneliti menyimpulkan beberapa hal sebagai berikut :

a. Di SMA Karya Ibu Palembang mata pelajaran Pendidikan Agama Islam diajarkan kepada siswa dengan alokasi waktu 3 jam pelajaran per minggu. Alokasi dua jam pelajaran memang sesuai dengan ketentuan dalam kurikulum 2004, sedangkan satu jam merupakan tambahan jam yang diambilkan dari sisa kalkulasi jam pelajaran secara keseluruhan dari mata pelajaran dalam satu Minggu.

b. Implementasi pembelajaran model peer teaching pada mata pelajaran Pendidikan Agama Islam di SMA Karya Ibu meliputi tiga tahap, yaitu tahap persiapan, tahap pelaksanaan dan tahap penilaian.

\section{Saran-Saran}


Dalam rangka meningkatkan mutu kegiatan Pembelajaran Pendidikan Agama Islam di SMA Karya Ibu Palembang, beberapa hal perlu diperhatikan dan dipertimbangkan oleh pihak pengelola sekolah, yaitu :

a. Agar tidak terjadi kejenuhan di dalam kegiatan pembelajaran diperlukan suatu variasi dalam kegiatan pembelajaran misalnya dengan out door activity. Dengan pembelajaran out door activity diharapkan siswa akan mendapatkan pengalaman dan suasana belajar yang menyenangkan (enjoyful lerning).

b. Pendidikan Agama Islam merupakan mata pelajaran yang kurang diminati oleh siswa karena tidak termasuk mata pelajaran yang diujikan secara Nasional. Oleh karena itu diharapkan guru agama agar dapat mengubah paradigma berfikir siswa terhadap mata pelajaran agama Islam. 


\section{DAFTAR PUSTAKA}

Arifin, M., 1991, Ilmu Pendidikan Islam: Suatu Tinjauan Teoritis dan Praktis Berdasarkan Pendekatan Indisipliner, Jakarta: Bumi Aksara.

Muliawan, Jasa Ungguh, 2005, Pendidikan Islam Integratif, Yogyakarta: Pustaka Pelajar.

Sardiman, A.M., 2001, Interaksi \& Motivasi Belajar Mengajar, Jakarta: PT. Raja Grafindo Persada.

Silberman, Mel, 2001, Active Learning: 101 Strategi Pembelajaran Aktif, Yogyakarta: YAPPENDIS.

Zamroni, 2007, Pendidikan dan Demokrasi dalam Transisi (Prakondisi Menuju Era Globalisasi), Jakarta: Muhammadiyah. 